BMJ

Open

Gastroenterology

\title{
Inability to walk: a rare presentation of Crohn's disease
}

\author{
Elmer Hoekstra $\odot,{ }^{1}$ Rudolf Keunen, ${ }^{2}$ Michael van der Voorn ${ }^{3}$
}

To cite: Hoekstra E, Keunen $\mathrm{R}$, van der Voorn M. Inability to walk: a rare presentation of Crohn's disease. BMJ Open Gastro 2020;7:e000526. doi:10.1136/ bmjgast-2020-000526

Received 29 August 2020 Revised 15 October 2020 Accepted 20 0ctober 2020
D Check for updates

(C) Author(s) (or their employer(s)) 2020. Re-use permitted under CC BY-NC. No commercial re-use. See rights and permissions. Published by BMJ.

${ }^{1}$ Department of Gastroenterology and Hepatology, Leiden Universitair Medisch Centrum, Leiden, Netherlands

${ }^{2}$ Department of Neurology, Haga Ziekenhuis, Den Haag, Netherlands

${ }^{3}$ Department of

Gastroenterology and Hepatology, Haga Ziekenhuis, Den Haag, Netherlands

Correspondence to Dr Elmer Hoekstra; e.hoekstra@lumc.nl

\section{ABSTRACT}

A wide variety of extraintestinal manifestations of inflammatory bowel disease (IBD) have been described, with joint or dermatological complaints as most prevalent. However, also neurological manifestations can occur, which are rarely recognised and therefore underreported. We present an very unusual case of a young man who presented with the inability to walk, as a first presentations of IBD.

\section{INTRODUCTION}

Inflammatory bowel diseases (IBDs) usually present with severe diarrhoea, abdominal pain, fatigue or weight loss. However, besides the gastrointestinal localisation of the diseases, multiple extraintestinal manifestations (EIM) have been described. Many organs can be involved, with the most common manifestations occurring musculoskeletal (joint pain, peripheral and axial arthropathies, arthritis) or dermatological (erythema nodosum, pyoderma gangrenosum, stomatitis). Less common organ involvement consist of renal, ocular or hepatobiliary tract. Underestimated and therefore also under-reported EIM of IBD are neurological complications. Here, we present a rare case, where a neurological manifestation appears to be the presenting symptom of IBD.

\section{CASE PRESENTATION}

A 43-year-old man presented to the neurology department with loss of strength and sensibility in the left upper leg, which started acutely 5 weeks ago. He could barely walk due to weakness of the quadriceps muscles. He does not use any medication, and his medical history noted bilateral hernia nucleus pulposi L2-L3 more than 20 years ago, which responded well to conservative treatment. On physical examination, there was apparent atrophic wasting of his quadriceps muscles on the left side (see figure 1), paresis of the quadriceps muscles and less apparent of the gluteus. His reflexes are all symmetric, besides a lower patellar reflex on

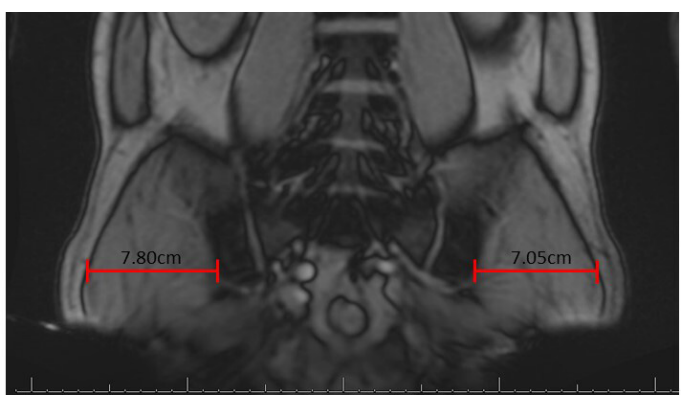

Figure 1 Lumbosacral MRI scan, showing no nerve root compression. On this MRI-scan the atrophic wasting of the left quadriceps muscle is apparent. Using image $\mathrm{J}$ quantification software, we found the diameter of the left leg was $7.05 \mathrm{~cm}$ as compared with $7.80 \mathrm{~cm}$ on the right side.

the left side. The patient reports no other complaints. However, on questioning, he noted that he had experienced a short period of abdominal pain 2 months ago with more frequent bowel movements at three times a day instead of once daily, without any blood loss. Laboratory tests show al slightly elevated CRP $(18 \mathrm{mg} / \mathrm{L})$ and ESR $(27 \mathrm{~mm} /$ hour$)$. Vitamin or electrolyte deficiencies (especially normal vitamin $\mathrm{B}_{1}, \mathrm{~B}_{6}, \mathrm{~B}_{12}$, folic acid levels

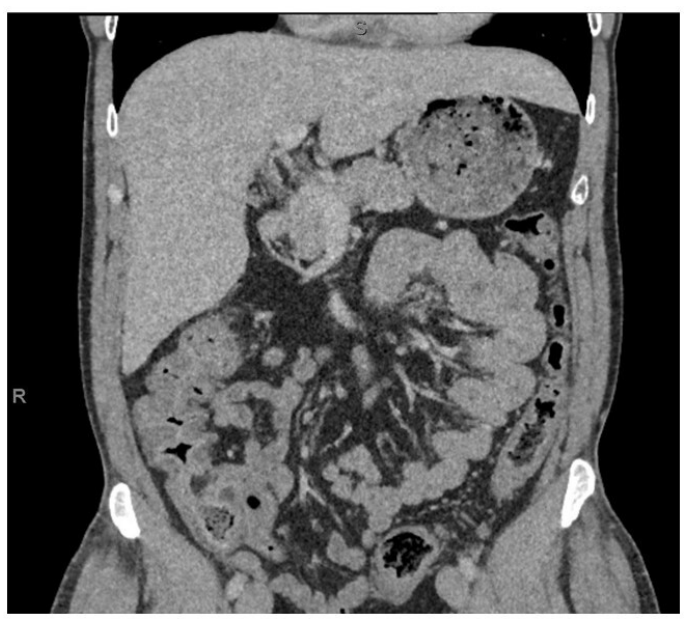

Figure 2 CT-scan of abdomen/pelvis, performed to examine any compression of the femoral nerve. This shows no compression, but an extensive colitis. 


\begin{tabular}{ll}
\hline \multicolumn{2}{l}{ Table 1 Laboratory results } \\
\hline Serum samples & Test result \\
\hline Vitamin $\mathrm{B}_{12}$ & $613 \mathrm{pmol} / \mathrm{L}(150-700 \mathrm{pmol} / \mathrm{L})$ \\
\hline Folic acid & $22.6 \mathrm{nmol} / \mathrm{L}(8.8-60.8 \mathrm{nmol} / \mathrm{L})$ \\
\hline Vitamin $\mathrm{B}_{1}$ & $143 \mathrm{nmol} / \mathrm{L}(66-186 \mathrm{nmol} / \mathrm{L})$ \\
\hline Vitamin $\mathrm{B}_{6}$ & $73 \mathrm{nmol} / \mathrm{L}(34-156 \mathrm{nmol} / \mathrm{L})$ \\
\hline Sodium & $140 \mathrm{mmol} / \mathrm{L}(136-145 \mathrm{mmol} / \mathrm{L})$ \\
\hline Potassium & $4.2 \mathrm{mmol} / \mathrm{L}(3.5-5.1 \mathrm{mmol} / \mathrm{L})$ \\
\hline Glucose (fasting) & $6.0 \mathrm{mmol} / \mathrm{L}(3.9-7.7 \mathrm{mmol} / \mathrm{L})$ \\
\hline Thyroid function $(\mathrm{TSH})$ & $1.3 \mathrm{mU} / \mathrm{L}(0.4-4.0 \mathrm{mU} / \mathrm{L})$ \\
\hline Prothrombin time; INR & $1.0(0.9-1.1)$ \\
\hline
\end{tabular}

INR, international normalized ratio; TSH, thyroid stimulating hormone.

and INR) were not present (table 1). Due to the medical history of bilateral hernia nucleus pulposi, lumbosacral MRI scan was performed, which showed discopathy of L4/L5 without any compression of the nerve roots. A needle electromyography (EMG) was performed, which showed active denervation/reinnervation of the vastus lateralis/vastus medialis/rectus femoris muscles, with no other muscles showing any abnormalities. This indicates a neuron fibre issue of the femoral nerve. The saphenous sensory nerve action potential was normal, which indicates there was no loss of velocity in the needle EMG, from which you can conclude there is a axonal problem and not loss of the myelin sheath, ruling out diseases like Guillain-Barre. In conclusion, the EMG showed isolated femoral nerve neuropathy, without any signs of plexopathy, myelin sheath disorder or motor neuron disease. Since the most common cause of isolated femoral nerve neuropathy is compression of the nerve, a CT scan of the abdomen/pelvis was performed. This showed no signs of compression of the femoral nerve, however, it did show a generalised colitis (figure 2).

Additional workup was performed with a markedly elevated faecal calprotectin level at $1721 \mathrm{mg} / \mathrm{kg}$, with stool cultures all negative (see table 2). Colonoscopy showed mild terminal ileitis, with mild-severe colitis throughout the entire colon, which endoscopically appears as Crohn's disease (figure 3). Pathology report showed active cryptitis with granuloma (figure 4), confirming the diagnosis

\begin{tabular}{ll}
\hline Table 2 Stool cultures & \\
\hline Stool samples & Test result \\
\hline Campolybacter species DNA (PCR) & Negative \\
\hline Campylobacter coli DNA (PCR) & Negative \\
\hline Campylobacter jejuni DNA (PCR) & Negative \\
Clostridium difficile tcbd gene DNA (PCR) & Negative \\
Salmonella species DNA (PCR) & Negative \\
Shigella species DNA (PCR) & Negative \\
Yersinia species DNA (PCR) & Negative \\
\hline
\end{tabular}

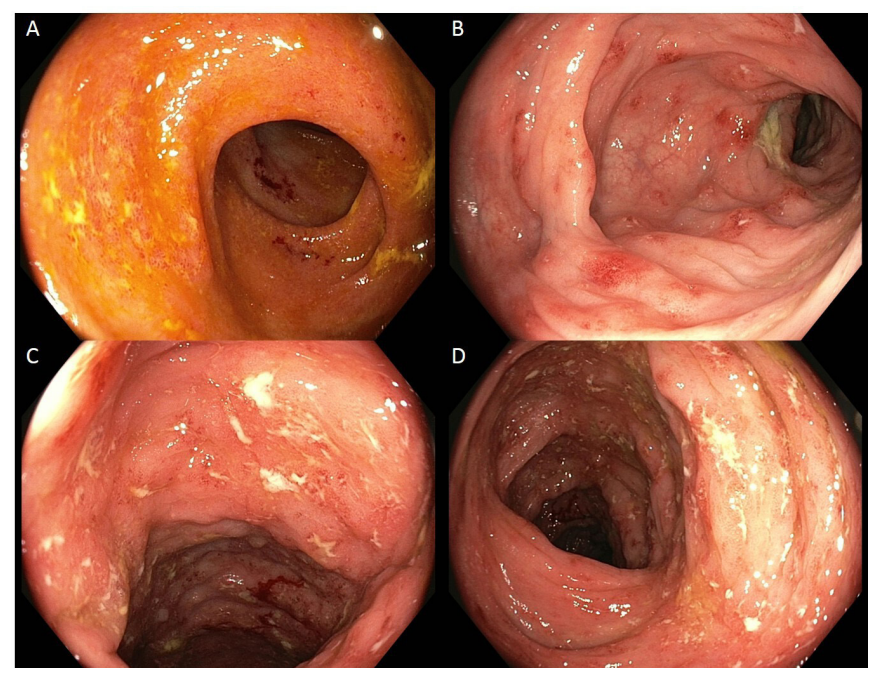

Figure 3 Colonoscopy results showing mild terminal ileitis (A) and moderate to severe colitis (B-D) with oedema, erythema and ulcers, endoscopically suspected for Crohn's disease.

Crohn's disease. The patient was started on steroids and immune modulators (budesonide and mercaptopurine). This resulted in long-term clinical and biochemical remission, with faecal calprotectin levels dropping to $5 \mathrm{mg} / \mathrm{kg}$. Surprisingly, together with achievement of remission of his Crohn's disease, his neuropathy resolved completely after the initiation of the IBD treatment.

\section{DISCUSSION}

Neuropathies as EIM of IBD have been reported before. ${ }^{1}$ Here, we present an intriguing case showing isolated femoral nerve neuropathy as EIM of IBD. Even more, in this case the femoral neuropathy was the presenting symptom of Crohn's disease. Neurological complications of IBD are one of the most under-reported EIM in IBD. Zois $e t$ al provide an overview of the literature on neurologic manifestations in IBD, showing that peripheral

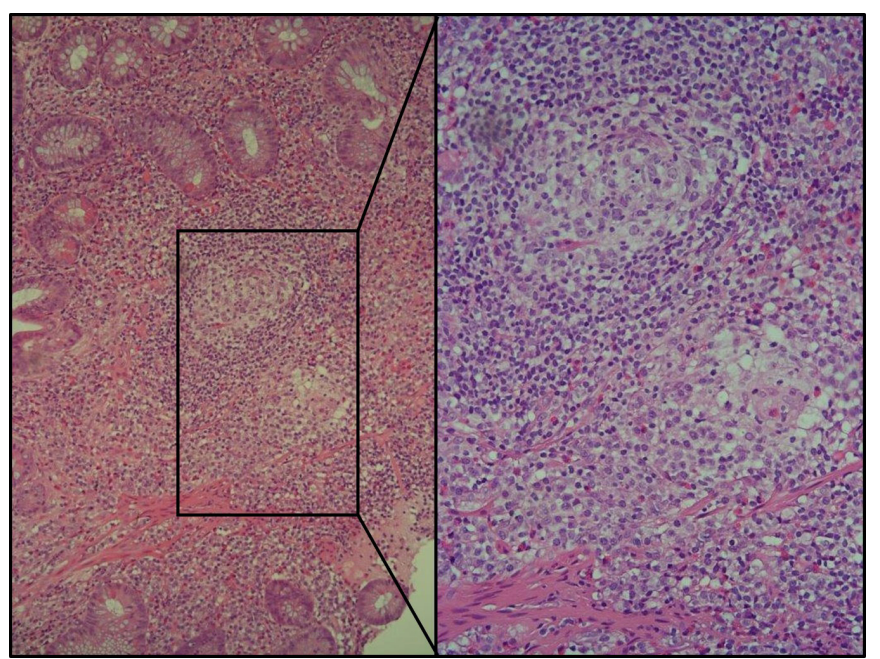

Figure 4 H\&E stains of inflamed gut tissue, with granulomas present (see enlarged figure). 
neuropathies are the most common feature. ${ }^{2}$ This is in agreement with an earlier report from Lossos, where the peripheral nervous system was affected in $31.5 \%$ of the patients ith IBD with neurological symptoms. ${ }^{1}$ In 2015, Garica-Cabo and Moris reviewed on the peripheral neuropathies in IBD. They conclude that peripheral nerve damage is very rare, but maybe also unrecognised and therefore under-reported complication of IBD. ${ }^{3}$ A large population-based cohort from the Mayo clinic described a neuropathy incidence rate was 72 cases per 100000 IBD person-years with a cumulative incidence rate of $2.4 \%$ after 30 years. ${ }^{4}$

The exact mechanism of the described neuropathy in this patient is unclear. Nutrient deficiencies can cause a similar phenotype, with vitamin $B_{12}$ as most important differential, which was not the case in our patient. Studies have also shown copper deficiency as causative agent for myelopathy or neuropathy. ${ }^{5}$ We have unfortunately not tested this in our patient, and were retrospectively not able to perform this test in our laboratory. However, the most common neurological phenomenon in these patients is a myelopathy, which is not the case in our patient. Furthermore, copper deficiency is frequently accompanied by haematological symptoms (ie,; anaemia/neutropenia) and is mostly seen in patients who underwent gastric surgery, both were not the case in our patient. Furthermore, vitamin E deficiency can also cause severe muscle weakness. However, the normal INR level in our patient serves as a marker that there is no severe deficiency of the fat-soluble vitamins

Taken together, the underlying pathogenesis of the reported association is yet to be elucidated, but most likely it has an immune basis. The complete and quick recovery of the femoral neuropathy after immunosuppressive therapy in our patient was impressive and supports this hypothesis. Therefore, we conclude this is a case showing neuropathy as EIM of IBD.
In summary, we present a very rare initial presentation of a common disease. This report highlights the importance of looking at Crohn's disease patients in a broader perspective, since a wide variety of EIM have been described, and the neurological manifestations are often overlooked.

Contributors EH, drafting of manuscript, main authorRK, drafting of manuscript. MvdV, including patient, drafting of manuscript

Funding The authors have not declared a specific grant for this research from any funding agency in the public, commercial or not-for-profit sectors.

Competing interests None declared.

Patient consent for publication Obtained.

Provenance and peer review Not commissioned; externally peer reviewed.

Data availability statement Data sharing not applicable as no datasets generated and/or analysed for this study.

Open access This is an open access article distributed in accordance with the Creative Commons Attribution Non Commercial (CC BY-NC 4.0) license, which permits others to distribute, remix, adapt, build upon this work non-commercially, and license their derivative works on different terms, provided the original work is properly cited, appropriate credit is given, any changes made indicated, and the use is non-commercial. See: http://creativecommons.org/licenses/by-nc/4.0/.

ORCID iD

Elmer Hoekstra http://orcid.org/0000-0001-8840-8294

\section{REFERENCES}

1 Lossos A, River Y, Eliakim A, et al. Neurologic aspects of inflammatory bowel disease. Neurology 1995;45:416-21.

2 Zois CD, Katsanos KH, Kosmidou M, et al. Neurologic manifestations in inflammatory bowel diseases: current knowledge and novel insights. J Crohns Colitis 2010;4:115-24.

3 García-Cabo C, Morís G. Peripheral neuropathy: an underreported neurologic manifestation of inflammatory bowel disease. Eur $\mathrm{J}$ Intern Med 2015;26:468-75.

4 Figueroa JJ, Loftus EV, Harmsen WS, et al. Peripheral neuropathy incidence in inflammatory bowel disease: a population-based study. Neurology 2013;80:1693-7.

5 Karlikaya G, Kaya D, Karlikaya G. A new differential diagnosis for acquired demyelinating neuropathy: copper deficiency. Neurol India 2014;62:434-5. 